\title{
Anxiety Profile of College Students during COVID-19 Pandemic: Descriptive and Comparative Study
}

\author{
Dhevy Puswiartika ${ }^{1}$, Bau Ratu $^{2}$, Misnah $^{3}$, Munifah $^{4}$, Micha Felayati Silalahi $^{5}$ \\ \{dhevyprodibk@gmail.com¹, bauratu74@gmail.com² ${ }^{2}$ misnah@untad.ac.id ${ }^{3}$, mouneeff.psi@gmail.com ${ }^{4}$, \\ silalahisinagiro0603@gmail.com $\left.{ }^{5}\right\}$ \\ Universitas Tadulako, Palu, Indonesia ${ }^{12345}$
}

\begin{abstract}
The change in learning methods from face-to-face learning to online learning was one of the academic pressures for college students during the COVID-19 pandemic that impacted college students' anxiety. This research aimed to explore and describe the anxiety profile of college students of the Faculty of Teacher Training and Education, Tadulako University, to determine appropriate psychological intervention to overcome it. The research also intended to test the difference in anxiety levels of college students based on the study program, department, and batch. The authors conducted explanatory survey research by distributing the anxiety scale $(\mathrm{a}=0,871)$ as a self-report. The sampling technique was a quota sampling technique. The participants were 117 college students from different study programs, departments, and batches. For the data analysis, the authors used descriptive statistics analysis and inferential analysis with the ANOVA test using Statistical Package for the Social Sciences software for Windows 21.0. The results of the descriptive analysis showed that generally, the respondents have high anxiety. The inferential analysis results showed significant differences in anxiety among college students based on the study program and department. On the other hand, there was no difference in anxiety levels among college students based on the batch. The results also suggest the urgency of the psychological intervention to overcome college students' anxiety to remain productive in participating in learning during the COVID-19 pandemic.
\end{abstract}

Keywords: Anxiety; College Students; COVID-19 Pandemic

\section{Introduction}

The COVID-19 pandemic situation has become an inseparable part of various aspects of life, such as health, social, economic, political, psychological, etc. The government urges the public to continue implementing the COVID-19 prevention protocol. On the other hand, during this pandemic, the Indonesian people are also required to live with a new life order, making peace with COVID-19 [1]. The goal of adapting to new habits is to continue to work, learn, and carry out productive activities in the era of the COVID-19 pandemic. In the education sector, the government issued a policy so that all teaching and learning activities both in schools and colleges are carried out using online methods to reduce physical interactions to prevent the spread of COVID-19 [2].

Online learning has several advantages in its application. Online learning makes teaching and learning activities accessible from various times and places. The use of online media also allows students to get broader information via the internet. This technology is considered very helpful in carrying out learning during social restrictions during the Covid-19 pandemic. The 
current generation of students is also close to technology, so that it is easier to adapt to online learning [3].

Various obstacles also arise in the application of online learning. Learning via the internet is challenging to do in certain areas with inadequate networks. The use of internet quotas also raises new expenses, which can be a problem for some students experiencing financial difficulties. Implementing online learning also depends on the readiness of the institution and. Not all teachers can deliver the entire material optimally through an online learning system [4].

The change in learning methods from face-to-face learning to online learning is one of the academic pressures for students during this pandemic. The implementation of the home study policy made some students feel anxious and depressed. The large number of tasks given by the teacher or lecturer made many students feel stressed about undergoing online learning. Not only a lot but the assignments given by the teacher or lecturer are also considered burdensome and have a short processing time, making students confused in completing their tasks [4].

In particular, researchers have conducted a preliminary study regarding the psychological condition of college students of Faculty of Teacher Training and Education, Tadulako University who took online learning during the COVID-19 pandemic. The results of this preliminary study using the online interview method showed that students experienced feelings of fear, worry, sadness, difficulty concentrating, tired quickly, and muscles felt tense and stiff. Students experience confusion when facing online learning methods accompanied by piles of assignments from lecturers. This condition causes anxiety in students.

Anxiety can be in the form of feeling worried, feeling bad, uncertain, or feeling very afraid as a result of a threat or threatening feeling where the natural source of the anxiety is not known with certainty [5]. Anxiety can affect student learning outcomes because anxiety tends to produce confusion and perceptual distortions. These distortions can interfere with the learning process by reducing the ability to focus attention, lowering memory, and interfering with connecting one thing to another [6].

Prolonged and ongoing anxiety can interfere with students' daily activities. The anxiety experienced by these students, if not treated immediately, can cause more serious psychological problems, which can have an impact on psychomotor manifestations in the form of a state of passion, enthusiasm, activity, and learning productivity which tends to decline. These psychomotor manifestations can affect decreasing student achievement. The anxiety of students who were evaluated during the pandemic period showed a much higher level of anxiety than the condition of students in regular times before the onset of the pandemic. The results of this study indicate that pandemic conditions have adverse psychological effects on students [7].

Referring to the preliminary study on anxiety from the authors and the previous researchers, the authors are interested in conducting a study to understand the profile of anxiety on the college students of Faculty of Teacher Training and Education, Tadulako University. This study is worth conducting to gain the profile of anxiety of college students for determine the psychological intervention to overcome college students 'anxiety to remain productive in participating in learning during the COVID-19 pandemic. The research questions in this research are: "How is the profile of anxiety of college students of Faculty of Teacher Training and Education, Tadulako University? "and "Are there any differences of anxiety of college students of Faculty of Teacher Training and Education, Tadulako University based on study program, department, and batch? “ 


\section{Methodology}

\subsection{Research Approach}

This study is quantitative research that uses the explanatory survey method and questionnaires to reveal and elaborate on the key information systematically, factually, and accurately. It consists of facts, tendencies, and attitudes of the phenomena of a particular population by conducting a study on a sample of that population [8]. In particular, this research is a comparative descriptive study to understand the description and differences of the anxiety of college students based on the study program, department, and batch.

\subsection{Participants}

The target population of this research is the college students of the Faculty of Teacher Training and Education, Tadulako University. The participants of this research are 117 college students. The sampling is taken by using the quota sampling technique, an unrestricted method that allows researchers to take population elements easily. The criteria for participants in this research are male and female gender, from four departments (Educational Science, Social Science, Natural Science, and Language), from 13 study program (Guidance and Counselling, Preschool Education, Elementary Education, Physical and Health Education, History, Citizenship Education, Geography, Mathematics, Physic, Chemistry, Biology, English, and Indonesian), and from 3 batches (2018, 2019, and 2020). The participants completed the survey and were ensured anonymity.

\subsection{Instrument}

The level of anxiety of college students is measured by using the anxiety scale as a selfreport modified by the authors from the Hamilton Rating Scale for Anxiety (HARS) based on research context $(a=0,871)$. This anxiety scale consists of 37 items covering four indicators: physical symptom, affective symptom, cognitive symptom, and psychomotor symptom.

\subsection{Data Analysis}

For the data analysis, the researchers used descriptive statistics analysis and inferential analysis with the Anova test using Statistical Package for the Social Sciences software for Windows 21.0. The descriptive statistical analysis was carried out to describe the number, percentage, and categorization of anxiety in participants. At the same time, the ANOVA test is used to see the differences in participants' anxiety based on study programs, department, and batch.

\section{Result and Discussion}

As seen in Table 1, the respondents are 117 college students of the Faculty of Teacher Training and Education, Tadulako University. The study program is dominated by the college students from History Study Program $(20,51 \%)$ and Guidance and Study Program $(17,09 \%)$. Based on department, the participant consists of Educational Science $(41,88 \%)$, Social Science $(34,19 \%)$, Natural Science $(13,68 \%)$, and Language $(10,26 \%)$. Based on the batch, the participants consist of 2018 batch (20,51\%), 2019 batch $(43,59 \%)$, and 2020 batch $(35,90 \%)$. 
Table 1. Respondent Demography Data

\begin{tabular}{llcc}
\hline \multicolumn{1}{c}{ Demography } & Frequency & Percentage \\
\hline Study & Grogram & & \\
& Preschool Education & 20 & $17,09 \%$ \\
& Elementary Education & 8 & $6,84 \%$ \\
& Physical and Health Education & 14 & $11,97 \%$ \\
& History & 7 & $5,98 \%$ \\
& Citizenship Education & 24 & $20,51 \%$ \\
& Geography & 9 & $7,69 \%$ \\
& Mathematics & 7 & $5,98 \%$ \\
& Physic & 4 & $3,42 \%$ \\
& Chemistry & 4 & $3,42 \%$ \\
& Biology & 4 & $3,42 \%$ \\
Department & 4 & $3,42 \%$ \\
& English & 7 & $5,98 \%$ \\
& Indonesian & 5 & $4,27 \%$ \\
& Educational Science & 49 & $41,88 \%$ \\
Social Science & 40 & $34,19 \%$ \\
& Natural Science & 16 & $13,68 \%$ \\
Total & Language & 12 & $10,26 \%$ \\
& 2018 & 24 & $20,51 \%$ \\
& 2019 & 51 & $43,59 \%$ \\
& 2020 & 42 & $35,90 \%$ \\
\end{tabular}

Based on the result in Table 2 shows that $34,19 \%$ of the respondents have a high level of anxiety, 28,21\% in moderate level, 19,66 \% in low level, 10,26 \% in very high level, and 7,69 $\%$ in very low level (Table 3 ). It indicates that generally, college students show high anxiety during the COVID-19 pandemic.

Table 2. Anxiety Level of Participant Based on Each Study Program

\begin{tabular}{lcccccc}
\hline Study Program & N & Very Low & Low & Moderate & High & Very High \\
\hline Guidance and Counselling & 20 & 1 & 4 & 1 & 12 & 2 \\
Preschool Education & 8 & 1 & 4 & 3 & 3 & 0 \\
Elementary Education & 14 & 2 & 3 & 1 & 2 & 0 \\
Physical and Health Education & 7 & 0 & 3 & 0 & 3 & 1 \\
History & 24 & 0 & 5 & 10 & 5 & 3 \\
Citizenship Education & 9 & 1 & 1 & 2 & 3 & 2 \\
Geography & 7 & 0 & 1 & 5 & 1 & 0 \\
Mathematics & 4 & 1 & 0 & 0 & 1 & 1 \\
Physic & 4 & 1 & 0 & 3 & 1 & 1 \\
Chemistry & 4 & 0 & 1 & 1 & 2 & 0 \\
Biology & 4 & 1 & 0 & 2 & 2 & 1 \\
English & 7 & 1 & 0 & 3 & 3 & 1 \\
Indonesian & 5 & 0 & 1 & 2 & 2 & 0 \\
Total & 117 & 9 & 23 & 33 & 40 & 12 \\
\hline
\end{tabular}


The normality test is used to determine whether the population of the data is normally distributed or not. Based on Table 3, the probability value (Sig.) is 0,794. This value is higher than 0,05 as a standard value. It can be concluded that the data are normally distributed. Therefore, the inferential analysis is tested with the Anova test. Table 4 and table 5 show that the inferential analysis results show that the probability values (Sig.) are 0,003 and 0,000. These values are lower than 0,05 as a standard value. It can be concluded that there are significant differences in the anxiety of college students based on study program and department.

On the other hand, based on table 6, the inferential analysis results show that the probability values (Sig.) are 0,442 . This value is higher than 0,05 as a standard value. It can be concluded that there is no significant difference in the anxiety of the college students based on the batch.

Table 3. Normality Test

\begin{tabular}{llr}
\hline & & Anxiety \\
\hline $\mathrm{N}$ & & 117 \\
Normal Parameters & Mean & 2.6128 \\
& Std. Deviation & .75847 \\
Most Extreme Differences & Absolute & .060 \\
& Positive & .054 \\
& Negative & -.060 \\
Kolmogorov-Smirnov Z & & .649 \\
Asymp. Sig. (2-tailed) & & .794 \\
\hline a. Test distribution is Normal. & & \\
b. Calculated from data. & &
\end{tabular}

Table 4. Difference Testing Based on Study Program

\begin{tabular}{ccccc}
\hline Study Program & N & Mean & F & Sig. \\
\hline Guidance and Counselling & 20 & 2.3608 & & \\
Preschool Education & 14 & 2.1795 & & \\
Elementary Education & 8 & 2.1081 & & \\
Physical and Health Education & 7 & 2.139 & & \\
History & 24 & 2.7185 & & \\
Citizenship Education & 9 & 2.982 & & \\
Geography & 7 & 2.9768 & 2.698 & \\
Mathematics & 4 & 2.6419 & & \\
Physic & 4 & 3.0203 & & \\
Chemistry & 4 & 2.5338 & & \\
Biology & 4 & 3.2027 & & \\
English & 7 & 3.3166 & & \\
Indonesian & 5 & 2.8811 & & \\
\hline
\end{tabular}

Table 5. Difference Testing Based on Department

\begin{tabular}{ccccc}
\hline Department & N & Mean & F & Sig. \\
\hline Educational Science & 49 & 2.2361 & & \\
Social Science & 40 & 2.823 & & 0,000
\end{tabular}




\begin{tabular}{cll} 
Natural Science & 16 & 2.8497 \\
Language & 12 & 3.1351 \\
\hline
\end{tabular}

Table 6. Difference Testing Based on Batch

\begin{tabular}{ccccc}
\hline Batch & N & Mean & F & Sig. \\
\hline 2018 & 24 & 2.473 & & \\
2019 & 51 & 2.7054 & 0.823 & 0.442 \\
2020 & 42 & 2.5804 & & \\
\hline
\end{tabular}

\section{Discussions}

The result showed that generally, college students show high anxiety during the COVID19 pandemic. This high level of anxiety score shows that the college students experience the anxiety symptoms, such as physical symptoms, cognitive symptoms, affective symptoms, and psychomotor symptoms. The college students feel physical symptoms, such as pain, tiredness, stomach pain, nausea, headache, and heart palpitations. For cognitive symptoms, they often experience attention deficit, decreased memory, and nightmare. They also feel affective symptoms, such as feeling worried, sensitive, sad, afraid, and moody. They experience nervousness, easy to cry, insomnia, wake up at night, and reduced interest in hobbies for psychomotor symptoms.

Furthermore, the comparative testing results showed significant differences in the anxiety of the college students based on the study program and department. If the results were reviewed from the mean score of anxiety based on the study program, the college students from the English study program had the highest mean score. The college students from the Elementary Education study program had the lowest mean score of anxiety. If the results were reviewed from the mean score of anxiety based on department, the college students from Language Department had the highest mean score of anxiety. The college students from Educational Science Department had the lowest mean score of anxiety.

Everyone's experience of anxiety could be different. Theoretically, anxiety is caused by personality, interpersonal, behavioral, social support, and biological factors [9], [10]. Specifically, regarding with personality factor, individual with introvert personality tend to feel anxious more easily than individual with extrovert personality [11]. The interview results with several participants of this research showed that generally the college students from the English study program and the Language Department had introvert personality. They had closed personality, self-oriented, and hard to get along. They prefer to keep their problems in their heart and didn't like to share their problems with the other people.

When they experience anxiety, they prefer to be alone and hesitant to ask for advice from others, so their anxiety increased. On the other hand, the college students from Elementary Education and Educational Science Department stated in generally they had extrovert personality. They had open personality. They tend to get along with other people easily. They prefer interaction with the other people. When they experienced anxiety, they always look for friends to share their problems until they are able to find a way out and their anxiety would decrease. 
On the other hand, the comparative testing results also showed no significant difference in the anxiety of the college students based on the batch. The college students from all the batch perceived the same anxiety. These results indicate that the COVID-19 pandemic factor is a situational factor that affects all groups, including students, regardless of the college entrance batch.

This condition indicates that urgently need an appropriate psychological intervention to overcome the college student's anxiety to remain productive in participating in learning during the COVID-19 pandemic. Anxiety can affect student learning outcomes because anxiety tends to produce confusion and perceptual distortions. These distortions can interfere with the learning process by reducing the ability to focus attention, lowering memory, and interfering with connecting one thing to another [6].

Prolonged and ongoing anxiety can interfere with students' daily activities. The anxiety experienced by these students, if not treated immediately, can cause more serious psychological problems, which can have an impact on psychomotor manifestations in the form of a state of passion, enthusiasm, activity, and learning productivity which tends to decline. These psychomotor manifestations can affect decreasing student achievement. The previous study results show that students who were evaluated during the pandemic period showed a much higher level of anxiety than the condition of students in regular times before the onset of the pandemic [7]. The results of this study indicate that pandemic conditions have adverse psychological effects on students.

One of the emerging methods of anxiety management is mindfulness. The mind precedes all things [12]. Therefore, mindfulness can be considered as being aware of one's thoughts. Mindfulness is present-centered attention-awareness in everyday experiences; aware of and attending to the present moment while accepting the situation for what it is [13]. How mindful a person is will vary across individuals, as an awareness of and attention to the present moment are thought to be inherent human abilities. Mindfulness has been proposed as a capability that people can learn and develop in order to enhance their relationship with experiences [14], [15] by mindfulness-based intervention as a self-regulation approach to stress reduction and emotional management [16].

Those who received mindfulness-based intervention appeared to be better able to recognize thoughts, emotions, and physical sensations as they arise under situations of impending stress [17]- [19], allowing them to respond to stressful situations in healthier and more adaptive ways. Mindfulness-based intervention may not only assist individuals in dealing with stressful life events. At the same time, they are occurring and prepare those entering highly stressful situations to regulate emotion better [20].

Currently, several mindfulness interventions programs have been implemented in the education sector. They have proven to have a positive impact on students, such as Mindfulness in Schools Programmed (MSP), Mindfulness-Based Wellness Education (MBWE), Cultivating Awareness and Resilience in Education (CARE), and Stress Management and Relaxation Techniques (SMART) [15], [16].

\section{Conclusion}

Referring to the result of this study, the authors conclude that the respondents generally show a high level of anxiety during the COVID-19 pandemic. This high level of anxiety score shows that the college students experience the anxiety symptoms, such as physical symptoms, 
cognitive symptoms, affective symptoms, and psychomotor symptoms. Furthermore, the comparative testing results showed significant differences in the anxiety of the college students based on the study program and department. On the other hand, the comparative testing results also showed no significant difference in the anxiety of the college students based on the batch. The college students from all the batch perceived the same anxiety. These results indicate that the COVID-19 pandemic factor is a situational factor that affects all groups, including students, regardless of the college entrance batch.

The research contributions of this study are the measurement and comparison of anxiety levels of college students. The study can also be helpful to the development of the concept and theory of mental health as a support to the development of guidance and counselling knowledge field. The result of this study can be used as a reference for the following study to explore appropriate psychological intervention to overcome the college students' anxiety to remain productive in participating in learning during the COVID-19 pandemic. One of the emerging methods of anxiety management is mindfulness. Currently, several mindfulness interventions programs have been implemented in the education sector and have proven to have a positive impact on students

However, this study has a limitation in quota sampling. It does neither represent the population of the research nor generalize the rest of the population. The future study can apply random sampling and add research samples to broaden the research generalization.

\section{References}

[1] E. Pranita and S. Nursastri, "5 Langkah Persiapkan 'New Normal' Jika Corona di Indonesia Berakhir.," 2020. https://www.kompas.com/sains/read/2020/05/12/170200723/5-langkahpersiapkan-new-normal-jika-corona-di-indonesia-berakhir. (Accessed Aug. 07, 2020).

[2] Pengelola Web Kemdikbud, "SE Mendikbud: Pembelajaran secara Daring dan Bekerja dari Rumah untuk Mencegah Penyebaran Covid-19," https://www.kemdikbud.go.id/main/blog/2020/03/se-mendikbud-pembelajaran-secara-daringdan-bekerja-dari-rumah-untuk-mencegah-penyebaran-covid19, Mar. 17, 2020.

[3] A. Pranoto, Sains dan Teknologi. Jakarta: PT Gramedia Pustaka Utama, 2009.

[4] P. Wahyono and H. Husamah, "Guru profesional di masa pandemi COVID-19: Review implementasi, tantangan, dan solusi pembelajaran daring," Jurnal Pendidikan Profesi Guru, vol. 1, no. 1, pp. 51-65, 2020, Accessed: Aug. 07, 2020. [Online]. Available: https://ejournal.umm.ac.id/index.php/jppg/article/view/12462/pdf.

[5] A. Nasir and A. Muhith, Dasar-dasar Keperawatan Jiwa: Pengantar dan Teori. Jakarta: Salemba Medika, 2011.

[6] B. J. Sadock and V. A. Saddock, Kaplan and Sadock's Comprehensive Textbook of Psychiatry, vol 1. 2005.

[7] B. R. Maia and P. C. Dias, "Anxiety, depression and stress in university students: the impact of COVID-19," Estud. psicol. (Campinas), vol. 37, no. e200067, 2020, doi: https://doi.org/10.1590/1982-0275202037e200067.

[8] J. W. Creswell, Research Design: Pendekatan Kualitatif, Kuantitatif, dan Campuran. Alih bahasa oleh Achmad Fawaid dan Rianayati Kusmini Pancasari. Yogyakarta: Pustaka Pelajar, 2017.

[9] G. W. Stuart and S. J. Sundeen, Pocket Guide to Psychiatric Nursing. St. Louis: Mosby Year Book, 2007.

[10] G. R. Thorn, A. Chosak, S. L. Baker, and D. H. Barlow, Psychological theories of panic disorder. London: Martin Dunitz Ltd, 1999.

[11] W. S. \& J. Ningsih, "Perbedaan Tingkat Kecemasan dalam menghadapi ujian antara Tipe Kepribadian Introvert dan Ekstrovert pada Mahasiswa Semester II Diploma Kesehatan Kemenkes Malang,” Jurnal Poltekkes Malang, 2012, Accessed: Jun. 09, 2021. [Online]. Available: http://jurnal.poltekkes-malang.ac.id/. 
[12] S. R. Bishop et al., "Mindfulness: A proposed operational definition," Clinical Psychology: Science and Practice, 2004, doi: 10.1093/clipsy/bph077.

[13] K. W. Brown and R. M. Ryan, "The benefits of being present: Mindfulness and its role in psychological well-being.," Journal of Personality and Social Psychology, vol. 84, no. 1, pp. 822848, 2003.

[14] J. Kabat-Zinn, wherever you go, there you are: Mindfulness meditation in everyday life. 1994.

[15] J. Kabat-Zinn, "Mindfulness-based interventions in context: Past, present, and future," Clinical Psychology: Science and Practice. 2003, doi: 10.1093/clipsy/bpg016.

[16] J. D. Creswell, “Mindfulness Interventions,” 2017. doi: 10.1146/annurev-psych-042716-051139.

[17] K. M. Sand, "Fostering Creativity: Adopting Mindfulness as an Innovative Approach to Managing Employee Stress," 2015.

[18] I. Schreiner and J. Malcolm, "The Benefits of Mindfulness Meditation: Changes in Emotional States of Depression, Anxiety, and Stress," Behaviour Change, vol. 25, no. 3, pp. 156-168, 2008, doi: doi:10.1375/bech.25.3.156.

[19] M. R. Tuckey, S. Sonnentag, and J. Bryan, "Are state mindfulness and state work engagement related during the workday?" Work and Stress, vol. 32, no. 1, 2018, doi: 10.1080/02678373.2017.1420707.

[20] J. J. Gross and R. Thompson, "Emotion regulation: Conceptual foundations," in J. J. Gross (Eds.) Handbook of Emotion Regulation, New York: Guilford Press, 2007. 